\title{
EFFECT OF WATER HARDNESS ON CORROSION BEHAVIOR OF MILD STEEL AT STEADY AERATION RATE
}

\section{Abd Elhamid Issa Hwwili ${ }^{\text {}}$, Talal A. Elmasri ${ }^{2}$, Mohammed Salah Mohammed ${ }^{1}$, Salih Ahmeed Salih ${ }^{1}$, Abu bakr Faraj Salih ${ }^{1}$}

${ }^{1}$ Department of Metallurgical and Materials Engineering, University of Ajdabiya, Ajdabiya, Libya. Email:

Abdelhamid.issa@uoa.edu.ly

${ }^{2}$ Department of Metallurgical and Materials Engineering, University of Ajdabiya, Ajdabiya, Libya. Email: talal_elmasri@uoa.edu.iy

HNSJ, 2022, 3(1); https://doi.org/10.53796/hnsj316

\section{Published at 01/01/2022}

\section{Accepted at 13/12/2021}

\begin{abstract}
Calcium and magnesium salts content controls the hardness of a water supply. These salts could form a combination with bicarbonates, sulfates, chlorides, and nitrates and precipitate as a solid which makes water more aggressive, destructive, and corrosive environment. In this paper; an experimental study was conducted in an attempt to determine a quantitative relationship between the hardness of heated water that responsible for alkaline and sulfur scales formation on metal surfaces and the corrosion penetration rate of carbon steel. Square (48) metal samples were cut from carbon steel sheets of known metallurgical composition manufactured by Libyan Iron and Steel Company in Misurata and supplied from General Pipe Company in Benghazi. The samples were prepared, measured and sorted into four groups and each of which separated in three samples. Each group of samples were immersed in a particular type of heated water at $100^{\circ} \mathrm{C}$ for different successive durations of immersion time. It was followed by an assigned exposure time (40 days) to the same water type. Four different aerated water sources and types were selected in this study to examine their associated hardness effect on mild steel corrosion penetration rate. The chemical analysis of the water types were carried out in Hawari GMRA headquarter laboratory in Benghazi. Distilled water diluted with seawater (1/2) had the highest total hardness (TH) of (8407.56 as ppm calcium carbonate), whereas the water of Great Man Made River (GMMR); Ajdabiya had the lowest $\mathrm{TH}$ of (208 ppm as $\left.\mathrm{CaCO}_{3}\right)$. The corrosion rate was measured based on the metal weight loss due to the immersion and exposure procedures and calculated as a corrosion penetration rate expressed in mils per year (mpy). The results displayed that an increase in the corrosion rate could be observed along with the total water hardness reduction for the three types of diluted seawater; in contrast, the lowest corrosion rate value was perceived in samples that immersed in (GMMR) water. It was also found that the immersion for more than 30 minutes in heated diluted seawater with $\mathrm{TH}$ of $(4203.7$ and $8407.5 \mathrm{mg} / \mathrm{L})$ results in a decrease in the corrosion rate.
\end{abstract}

Key Words: corrosion rates, aerated water, and water hardness 


\section{INTRODUCTION}

Corrosion of metals is viewed as one of the most serious designing problem confronting these days. Enormous areas of modern industry and structural designing development projects risking their financial and specialized plausibility. Thusly, it is judicious to consider the issue of corrosion from the very beginning to any. Venture with the end goal that plan inspections to consider corrosion and its anticipation are executed in a very basic methodology dependent on solid hypothetical and practical designing. Material selection is viewed as one of the most mind-blowing early prevention techniques with the end goal that earlier information on corrosion behavior of any metal or alloy is anticipated to the plan engineer before the individual chooses any metal for construction to limit future failures of equipment because of corrosion. Assessment of corrosion rate of any metal or alloy in a simulated corrosive environment is one of the best tools of settling on early decisions about longterm, real-time equipment performance. There are numerous strategies for corrosion rate estimation procedures revealed in the literatures, and among them the weight loss technique is by a wide margin viewed as awesome since it simulates the real corrosion behavior of many metals or alloys in some random environment under test $[1,3]$.

Corrosion is firmly identified with the nature of the material presented to corrosion and the nature of the corrosive medium. There are countless corrosive guides that show various sorts of wear. The most significant of these circles are the climate, water, soil acids, and salts, when performed. Tests and tests for corrosion in a given water and mineral medium, most importantly cautious investigation of both the medium and the metal, to decide the sort and rate of wear that every medium will cause. Corrosion rates have been communicated in a variety of ways in the literatures, for example, percent weight reduction, milligrams per square centimeter each day, and grams per square inch each hour. These do not state corrosion resistance in terms of penetration. From a designing perspective, the rate of penetration, or the diminishing of a component, can be utilized to expect the life of a given part. Mils penetration each year (mpy) is the most usually utilized corrosion rate articulation. It expresses corrosion rate as far as penetration utilizing small integers. This expression is easily determined from the weight loss of the metal sample during the corrosion test by the equation given below:

$$
m p y=\frac{534 W}{D A T}
$$

Where $\mathrm{W}$ is the weight loss $(\mathrm{mg})$ after exposure time $\mathrm{t}(\mathrm{hr}$.$) ; D and A represent the density \left(\mathrm{g} / \mathrm{cm}^{3}\right)$ and exposed specimen area $\left(\mathrm{in}^{2}\right)$ respectively $[2,4]$.

Natural fresh waters contain disintegrated calcium and magnesium salts in fluctuating concentrations, contingent upon the source and area of the water. In the event that the grouping of such salts is high, the water is called hard; else, it is called soft. It was perceived for a long time before the causes were obviously perceived that the soft water was more corrosive than the hard water. For instance, a galvanized-iron hot-water tank was seen to last 10 to 20 years prior to failing by pitting in Chicago Great Lakes water ( $34 \mathrm{ppm} \mathrm{Ca}{ }^{2+}, 157 \mathrm{ppm}$ broke up solids), though in Boston water (5 ppm Ca ${ }^{2+}, 43$ ppm dissolved solids) a comparative tank endured just one to two years. The tool of protection gave by a hard water is the regular deposition on the metal surface of a thin diffusion-barrier film, composed mainly of calcium carbonate $\left(\mathrm{CaCO}_{3}\right)$. This film delays diffusion of broke up oxygen to cathodic regions, enhancing the natural corrosion fence of $\mathrm{Fe}(\mathrm{OH})_{2}$ cited before. In soft waters no such defensive film of $\mathrm{CaCO}_{3}$ can shape. However, hardness alone is not the main factor that decides if a defensive film is possible. Capacity of $\mathrm{CaCO}_{3}$ to precipitate on the metal surface additionally relies upon complete acidity or alkalinity, $\mathrm{PH}$, and concentration of dissolved solids in the water [5]. The main purpose of this study is to investigate the effect of adhered scales due to natural hardness of water on corrosion rate with respect to temperature and immersion time.

\section{EXPERIMENTAL SECTION}

\subsection{Materials and Apparatuses}

Plenty of different experimental procedures were done in this study on 48 squared cross-sectional area of ASTM A36 Steel, plate samples $(2.5 \mathrm{~cm}$ x $2.5 \mathrm{~cm})$ with identical small thickness (Figure 1a). 
The detailed chemical composition of the steel alloy is known and provided as a technical data sheet from the manufacturer "Misurata Iron and Steel Factory". A small hole was drilled in one corner of each sample to facilitate suspension and attaching the sample identification code number using a strong steel fishing wire as illustrated in Figure 1b. Simple tools and devices were used to accomplish this study which specifically are a moderate power water heater, a mercury thermometer, four glass containers, a digital weighting scale and oxygen pump.

\subsection{Tests and Experimental Procedures}

Several experimental steps and measurements were done on the 48 steel samples in various aerated water baths with different compositions at altered temperatures. Man-made Ajdabiya river water and a mixture of seawater and distilled water by different concentrations were selected and analyzed in order to investigate the effect of their hardness on low carbon steel corrosion rate as following:

- Each sample was cleaned separately using different emery papers (P1000) (P800) (P600) (P400) and then polished until a bright metal surface was obtained for all sides.

- The length, width and thickness of each sample was accurately measured to the nearest millimeter by using Caliper Vernier.

- The weight of each sample was determined to the nearest milligrams. A digital weighting scale available at the Physics Laboratory at Ajdabiya University was used to carry out all weighting measurements.

- Physical and chemical analysis of one liter samples of each water type were performed. These chemical analysis processes accomplished in (GMRA) main headquarter lab in Hawari; Benghazi (Table 1).

- Twelve (12) samples were assigned for each type of water, and sorted into four groups (three samples per each group). One group samples were directly exposed to water, while the other groups exposed to three sequential periods of immersion time (15 minutes duration) in heated water at $100^{\circ} \mathrm{C}$ (Figure 1c) followed by an exposure time (40 days) to the same type of water at ambient temperature.

- Four equal size glass containers were filled with four different types of water, each container was equipped with an air pump to circulate and pump oxygen bubbles into each container in an attempt to maintain a stable dissolved oxygen concentration at all times during the experiment.

- At end of exposing time (Figure 1d), the samples were cleaned using rubber stoppers and soft emery paper until the shiny metal surface appeared again, and reweighted with a view to determine the weight loss.
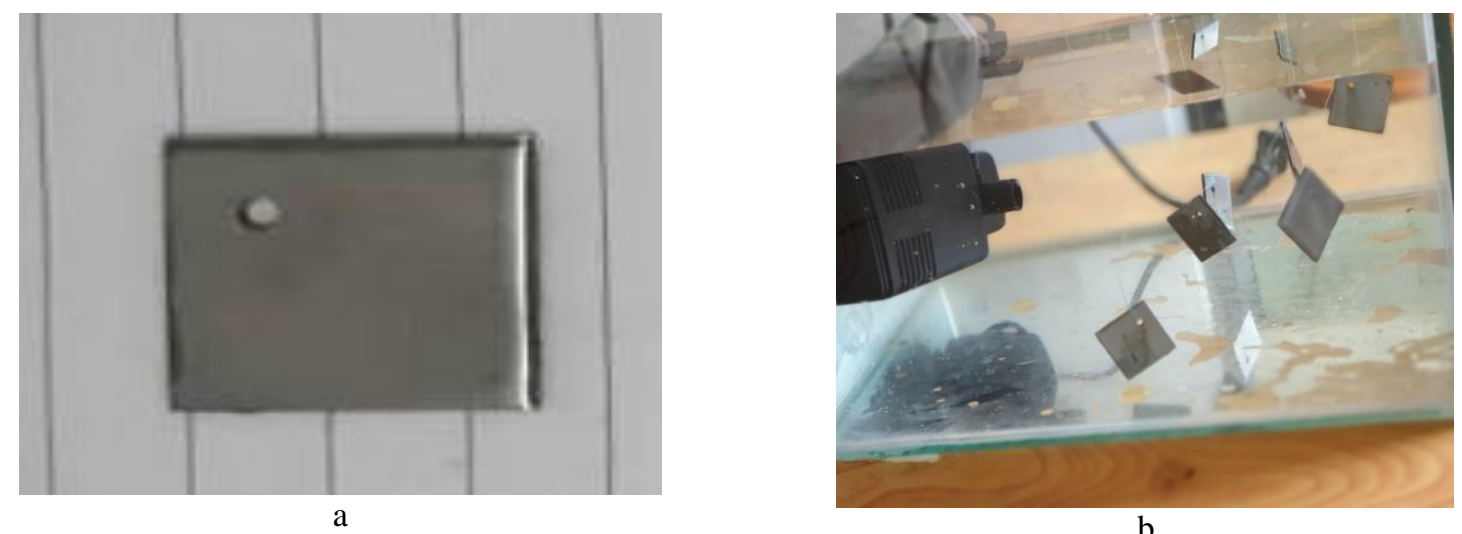

b 

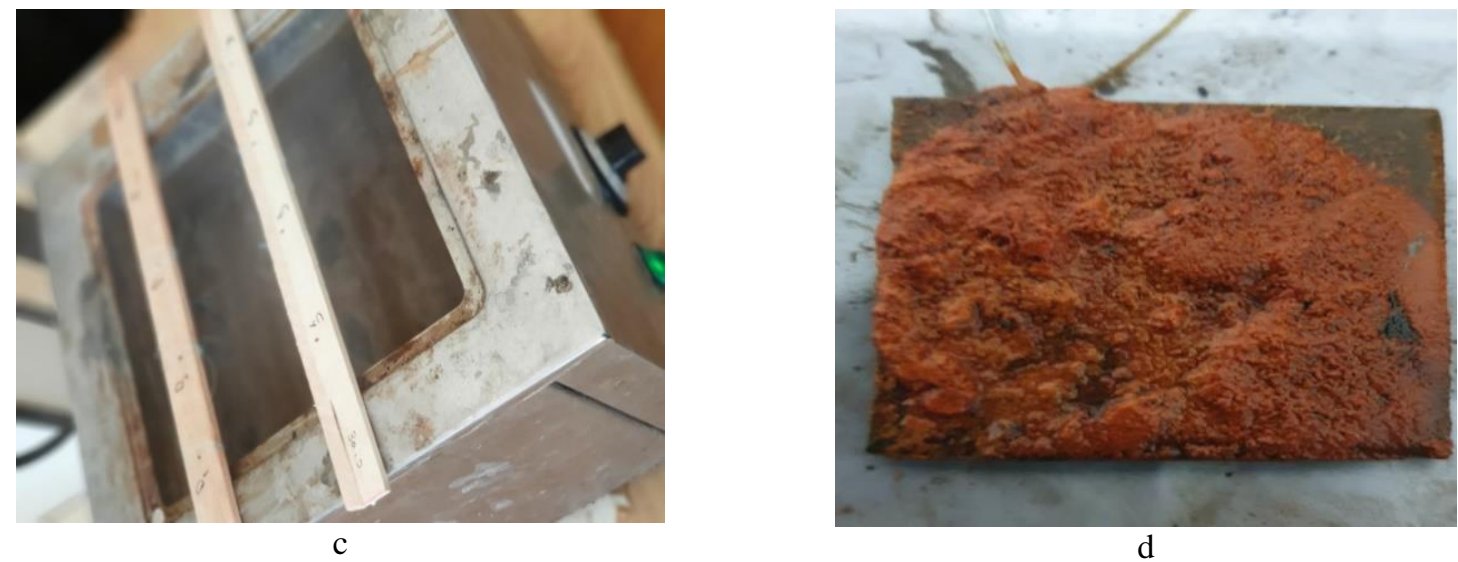

Figure 1: Representations of (a) a finished sample, (b) suspension of samples in aerated water, (c) heating of samples and (d) a sample after exposure time

Table 1: The chemical analysis of one liter samples of each water type

\begin{tabular}{|c|c|c|c|c|c|}
\hline Samples & $\begin{array}{c}\text { Temperature } \\
\left({ }^{\circ} \mathrm{C}\right)\end{array}$ & $\mathrm{PH}$ & $\begin{array}{c}\text { Total Dissolved } \\
\text { Solid (TDS) } \\
\mathrm{mg} / \text { /lter }\end{array}$ & $\begin{array}{c}\text { Total Hardness } \\
(\mathrm{TH}) \\
\mathrm{mg} \mathrm{CaCO} / \mathrm{L}\end{array}$ & $\begin{array}{c}\text { Calcium } \\
\text { Hardness (Ca.H) } \\
\mathrm{mg} \mathrm{CaCO}_{3} / \mathrm{L}\end{array}$ \\
\hline GMMR & 22.2 & 8.6 & 721.5 & 208.19 & 88.08 \\
\hline $1 / 2$ & 22.2 & 6.8 & 19695 & 8407.56 & 1601.44 \\
\hline $1 / 4$ & 22.2 & 6.9 & 14170 & 6305.67 & 1100.99 \\
\hline $1 / 8$ & 22.2 & 7.3 & 14105 & 4203.78 & 900.81 \\
\hline
\end{tabular}

\section{RESULTS}

Tables (2) through (5) summarize the experimental weight loss measurements in milligrams of all 48 tested samples in the four types of water, and their corresponding corrosion rates that expressed in mils of penetration per year. Figure (2) gives combined plots of corrosion rates in mpy as a function of immersion time periods of each set of samples in heated and thermostated water at $100^{\circ} \mathrm{C}$ of the four under consideration water types.

Table 2: The experimental results of $W$ and mpy for samples tested in (GMMR) water

\begin{tabular}{|c|c|c|c|c|c|c|c|c|c|}
\hline \multirow{2}{*}{$\begin{array}{l}\text { Sample's } \\
\text { Label }\end{array}$} & \multirow{2}{*}{$\begin{array}{l}\text { Immersion } \\
\text { time (min) }\end{array}$} & \multirow{2}{*}{$\begin{array}{l}\text { Initial } \\
\text { Weight } \\
\text { (mg) }\end{array}$} & \multirow{2}{*}{$\begin{array}{c}\text { Final } \\
\text { weight } \\
\text { (mg) }\end{array}$} & \multirow{2}{*}{$\begin{array}{c}\text { Weight } \\
\text { Loss } \\
(\mathrm{mg})\end{array}$} & \multirow{2}{*}{$\begin{array}{c}\text { Exposure } \\
\text { Time } \\
\text { (hours) }\end{array}$} & \multirow{2}{*}{$\begin{array}{c}\text { Sample's } \\
\text { Total } \\
\text { Surface } \\
\text { Area } \\
\left(\text { in }^{2}\right)\end{array}$} & \multirow{2}{*}{$\begin{array}{l}\text { Density } \\
\left(\mathrm{g} / \mathrm{cm}^{3}\right)\end{array}$} & \multicolumn{2}{|c|}{$\begin{array}{l}\text { Corrosion Rate } \\
\text { (mpy) }\end{array}$} \\
\hline & & & & & & & & /Sample & $\begin{array}{c}\text { An } \\
\text { average }\end{array}$ \\
\hline $\begin{array}{l}\text { A1 } \\
\text { A2 } \\
\text { A3 }\end{array}$ & 0 & $\begin{array}{c}10088 \\
9975 \\
10071\end{array}$ & $\begin{array}{l}9834.7 \\
9706.3 \\
9788.4\end{array}$ & $\begin{array}{l}253.3 \\
268.7 \\
282.6\end{array}$ & 960 & 2.46 & 7.85 & $\begin{array}{l}7.296 \\
7.739 \\
8.140\end{array}$ & 7.725 \\
\hline $\begin{array}{l}\text { B1 } \\
\text { B2 } \\
\text { B3 }\end{array}$ & 15 & $\begin{array}{l}10020 \\
10023 \\
10010\end{array}$ & $\begin{array}{l}9738.7 \\
9866.6 \\
9707.4\end{array}$ & $\begin{array}{l}281.3 \\
156.4 \\
302.6\end{array}$ & 960 & 2.46 & 7.85 & $\begin{array}{l}8.102 \\
4.505 \\
8.716\end{array}$ & 7.107 \\
\hline $\begin{array}{l}\mathrm{C} 1 \\
\mathrm{C} 2 \\
\mathrm{C} 3 \\
\end{array}$ & 30 & $\begin{array}{c}10016 \\
9946 \\
9984 \\
\end{array}$ & $\begin{array}{l}9803.5 \\
9740.4 \\
9713.9 \\
\end{array}$ & $\begin{array}{l}222.5 \\
205.6 \\
270.1 \\
\end{array}$ & 960 & 2.46 & 7.85 & $\begin{array}{l}6.409 \\
5.922 \\
7.780 \\
\end{array}$ & 6.703 \\
\hline $\begin{array}{l}\text { D1 } \\
\text { D2 } \\
\text { D3 }\end{array}$ & 40 & $\begin{array}{c}9994 \\
9974 \\
10065\end{array}$ & $\begin{array}{l}9723.6 \\
9732.4 \\
9787.3\end{array}$ & $\begin{array}{l}270.4 \\
241.6 \\
277.7\end{array}$ & 960 & 2.46 & 7.85 & $\begin{array}{l}7.788 \\
6.959 \\
7.999\end{array}$ & 7.582 \\
\hline
\end{tabular}


Table 3: The experimental findings of $W$ and mpy for samples tested in (1/2) distilled/seawater mixture

\begin{tabular}{|c|c|c|c|c|c|c|c|c|c|}
\hline \multirow{2}{*}{$\begin{array}{c}\text { Sample's } \\
\text { Label }\end{array}$} & \multirow{2}{*}{$\begin{array}{l}\text { Immersion } \\
\text { time (min) }\end{array}$} & \multirow{2}{*}{$\begin{array}{l}\text { Initial } \\
\text { Weight } \\
\text { (mg) }\end{array}$} & \multirow{2}{*}{$\begin{array}{l}\text { Final } \\
\text { weight } \\
(\mathrm{mg})\end{array}$} & \multirow{2}{*}{$\begin{array}{c}\text { Weight } \\
\text { Loss } \\
\text { (mg) }\end{array}$} & \multirow{2}{*}{$\begin{array}{l}\text { Exposure } \\
\text { Time } \\
\text { (hours) }\end{array}$} & \multirow{2}{*}{$\begin{array}{c}\text { Sample's } \\
\text { Total } \\
\text { Surface } \\
\text { Area } \\
\left(\mathrm{in}^{2}\right)\end{array}$} & \multirow{2}{*}{$\begin{array}{l}\text { Density } \\
\left(\mathrm{g} / \mathrm{cm}^{3}\right)\end{array}$} & \multicolumn{2}{|c|}{$\begin{array}{l}\text { Corrosion Rate } \\
\text { (mpy) }\end{array}$} \\
\hline & & & & & & & & /Sample & $\begin{array}{c}\text { An } \\
\text { average }\end{array}$ \\
\hline E1 & \multirow{3}{*}{0} & 10074 & 9847.6 & 226.4 & \multirow{3}{*}{960} & \multirow{3}{*}{2.46} & \multirow{3}{*}{7.85} & 6.521 & \multirow{3}{*}{7.452} \\
\hline $\mathrm{E} 2$ & & 9866 & 9696.3 & 169.7 & & & & 4.888 & \\
\hline E3 & & 10017 & 9636.9 & 380.1 & & & & 10.948 & \\
\hline F1 & \multirow{3}{*}{15} & 9988 & 9723.1 & 264.9 & \multirow{3}{*}{960} & \multirow{3}{*}{2.46} & \multirow{3}{*}{7.85} & 7.630 & \multirow{3}{*}{8.103} \\
\hline $\mathrm{F} 2$ & & 10069 & 9794 & 275 & & & & 7.921 & \\
\hline F3 & & 10075 & 9770.9 & 304.1 & & & & 8.759 & \\
\hline G1 & \multirow{3}{*}{30} & 9876 & 9605.8 & 270.2 & \multirow{3}{*}{960} & \multirow{3}{*}{2.46} & \multirow{3}{*}{7.85} & 7.783 & \multirow{3}{*}{8.175} \\
\hline $\mathrm{G} 2$ & & 9856 & 9634.7 & 221.3 & & & & 6.374 & \\
\hline G3 & & 9848 & 9488 & 360 & & & & 10.369 & \\
\hline $\mathrm{H} 1$ & \multirow{3}{*}{45} & 10166 & 9942 & 224 & \multirow{3}{*}{960} & \multirow{3}{*}{2.46} & \multirow{3}{*}{7.85} & 6.452 & \multirow{3}{*}{6.335} \\
\hline $\mathrm{H} 2$ & & 10154 & 9948.9 & 205.1 & & & & 5.907 & \\
\hline H3 & & 10139 & 9908.2 & 230.8 & & & & 6.648 & \\
\hline
\end{tabular}

Table 4: The experimental results of $W$ and mpy for samples tested in (1/4) distilled/seawater mixture

\begin{tabular}{|c|c|c|c|c|c|c|c|c|c|}
\hline \multirow{2}{*}{$\begin{array}{l}\text { Sample's } \\
\text { Label }\end{array}$} & \multirow{2}{*}{$\begin{array}{l}\text { Immersion } \\
\text { time (min) }\end{array}$} & \multirow{2}{*}{$\begin{array}{l}\text { Initial } \\
\text { Weight } \\
\text { (mg) }\end{array}$} & \multirow{2}{*}{$\begin{array}{c}\text { Final } \\
\text { weight } \\
\text { (mg) }\end{array}$} & \multirow{2}{*}{$\begin{array}{l}\text { Weight } \\
\text { Loss } \\
\text { (mg) }\end{array}$} & \multirow{2}{*}{$\begin{array}{c}\text { Exposure } \\
\text { Time } \\
\text { (hours) }\end{array}$} & \multirow{2}{*}{$\begin{array}{c}\text { Sample's } \\
\text { Total } \\
\text { Surface } \\
\text { Area } \\
\left(\mathrm{in}^{2}\right)\end{array}$} & \multirow{2}{*}{$\begin{array}{l}\text { Density } \\
\left(\mathrm{g} / \mathrm{cm}^{3}\right)\end{array}$} & \multicolumn{2}{|c|}{$\begin{array}{l}\text { Corrosion Rate } \\
\text { (mpy) }\end{array}$} \\
\hline & & & & & & & & /Sample & $\begin{array}{c}\text { An } \\
\text { average }\end{array}$ \\
\hline $\begin{array}{l}\text { I1 } \\
\text { I2 } \\
\text { I3 } \\
\text { I4 } \\
\end{array}$ & 0 & $\begin{array}{c}9928 \\
10103 \\
10009\end{array}$ & $\begin{array}{l}9716.6 \\
9844.3 \\
9757.9\end{array}$ & $\begin{array}{l}211.4 \\
258.7 \\
251.1\end{array}$ & 960 & 2.46 & 7.85 & $\begin{array}{l}6.089 \\
7.451 \\
7.232\end{array}$ & 6.924 \\
\hline $\begin{array}{l}\mathrm{J} 1 \\
\mathrm{~J} 2 \\
\mathrm{~J} 3 \\
\mathrm{~J} 4\end{array}$ & 15 & $\begin{array}{c}9831 \\
9988 \\
10094\end{array}$ & $\begin{array}{c}9548 \\
9722.4 \\
9803.7\end{array}$ & $\begin{array}{c}283 \\
265.6 \\
290.3\end{array}$ & 960 & 2.46 & 7.85 & $\begin{array}{l}8.151 \\
7.650 \\
8.362\end{array}$ & 8.054 \\
\hline $\begin{array}{l}\text { K1 } \\
\text { K2 } \\
\text { K3 } \\
\text { K4 }\end{array}$ & 30 & $\begin{array}{c}9943 \\
9950 \\
10104\end{array}$ & $\begin{array}{l}9635.5 \\
9635.8 \\
9824.4\end{array}$ & $\begin{array}{l}307.5 \\
314.2 \\
279.6\end{array}$ & 960 & 2.46 & 7.85 & $\begin{array}{l}8.857 \\
9.050 \\
8.053\end{array}$ & 8.653 \\
\hline $\begin{array}{l}\text { L1 } \\
\text { L2 } \\
\text { L3 } \\
\text { L4 }\end{array}$ & 45 & $\begin{array}{c}9762 \\
10046 \\
9981\end{array}$ & $\begin{array}{c}9440.5 \\
9692.7 \\
9692\end{array}$ & $\begin{array}{c}321.5 \\
353.3 \\
289\end{array}$ & 960 & 2.46 & 7.85 & $\begin{array}{c}9.260 \\
10.176 \\
8.324\end{array}$ & 9.253 \\
\hline
\end{tabular}

Table 5: The experimental outcomes of $W$ and mpy for samples tested in (1/8) distilled/seawater mixture

\begin{tabular}{|c|c|c|c|c|c|c|c|c|c|}
\hline \multirow{2}{*}{$\begin{array}{c}\text { Sample's } \\
\text { Label }\end{array}$} & \multirow{2}{*}{$\begin{array}{l}\text { Immersion } \\
\text { time (min) }\end{array}$} & \multirow{2}{*}{$\begin{array}{l}\text { Initial } \\
\text { Weight } \\
\text { (mg) }\end{array}$} & \multirow{2}{*}{$\begin{array}{c}\text { Final } \\
\text { weight } \\
(\mathrm{mg})\end{array}$} & \multirow{2}{*}{$\begin{array}{c}\text { Weight } \\
\text { Loss } \\
(\mathrm{mg})\end{array}$} & \multirow{2}{*}{$\begin{array}{c}\text { Exposure } \\
\text { Time } \\
\text { (hours) }\end{array}$} & \multirow{2}{*}{$\begin{array}{c}\text { Sample's } \\
\text { Total } \\
\text { Surface } \\
\text { Area } \\
\left(\text { in }^{2}\right)\end{array}$} & \multirow{2}{*}{$\begin{array}{l}\text { Density } \\
\left(\mathrm{g} / \mathrm{cm}^{3}\right)\end{array}$} & \multicolumn{2}{|c|}{$\begin{array}{l}\text { Corrosion Rate } \\
\text { (mpy) }\end{array}$} \\
\hline & & & & & & & & /Sample & $\begin{array}{c}\text { An } \\
\text { average }\end{array}$ \\
\hline M1 & \multirow{3}{*}{0} & 9928 & 9564.1 & 363.9 & \multirow{3}{*}{960} & \multirow{3}{*}{2.46} & \multirow{3}{*}{7.85} & 10.482 & \multirow{3}{*}{10.063} \\
\hline M2 & & 9980 & 9634.9 & 345.1 & & & & 9.940 & \\
\hline M3 & & 9952 & 9612.9 & 339.1 & & & & 9.767 & \\
\hline N1 & \multirow{3}{*}{15} & 10103 & 9666.1 & 436.9 & \multirow{3}{*}{960} & \multirow{3}{*}{2.46} & \multirow{3}{*}{7.85} & 12.584 & \multirow{3}{*}{11.496} \\
\hline N2 & & 10004 & 9596.9 & 407.1 & & & & 11.726 & \\
\hline N3 & & 9994 & 9640.6 & 353.4 & & & & 10.179 & \\
\hline $\mathrm{P} 1$ & \multirow{3}{*}{30} & 9985 & 9479.8 & 505.2 & \multirow{3}{*}{960} & \multirow{3}{*}{2.46} & \multirow{3}{*}{7.85} & 14.552 & \multirow{3}{*}{13.315} \\
\hline $\mathrm{P} 2$ & & 9943 & 9485.3 & 457.7 & & & & 13.183 & \\
\hline P3 & & 9770 & 9346.1 & 423.9 & & & & 12.210 & \\
\hline Q1 & \multirow{3}{*}{45} & 9675 & 9267.3 & 407.7 & \multirow{3}{*}{960} & \multirow{3}{*}{2.46} & \multirow{3}{*}{7.85} & 11.743 & \multirow{3}{*}{11.076} \\
\hline Q2 & & 10025 & 9650.9 & 374.1 & & & & 10.775 & \\
\hline Q3 & & 9968 & 9596.1 & 371.9 & & & & 10.712 & \\
\hline
\end{tabular}




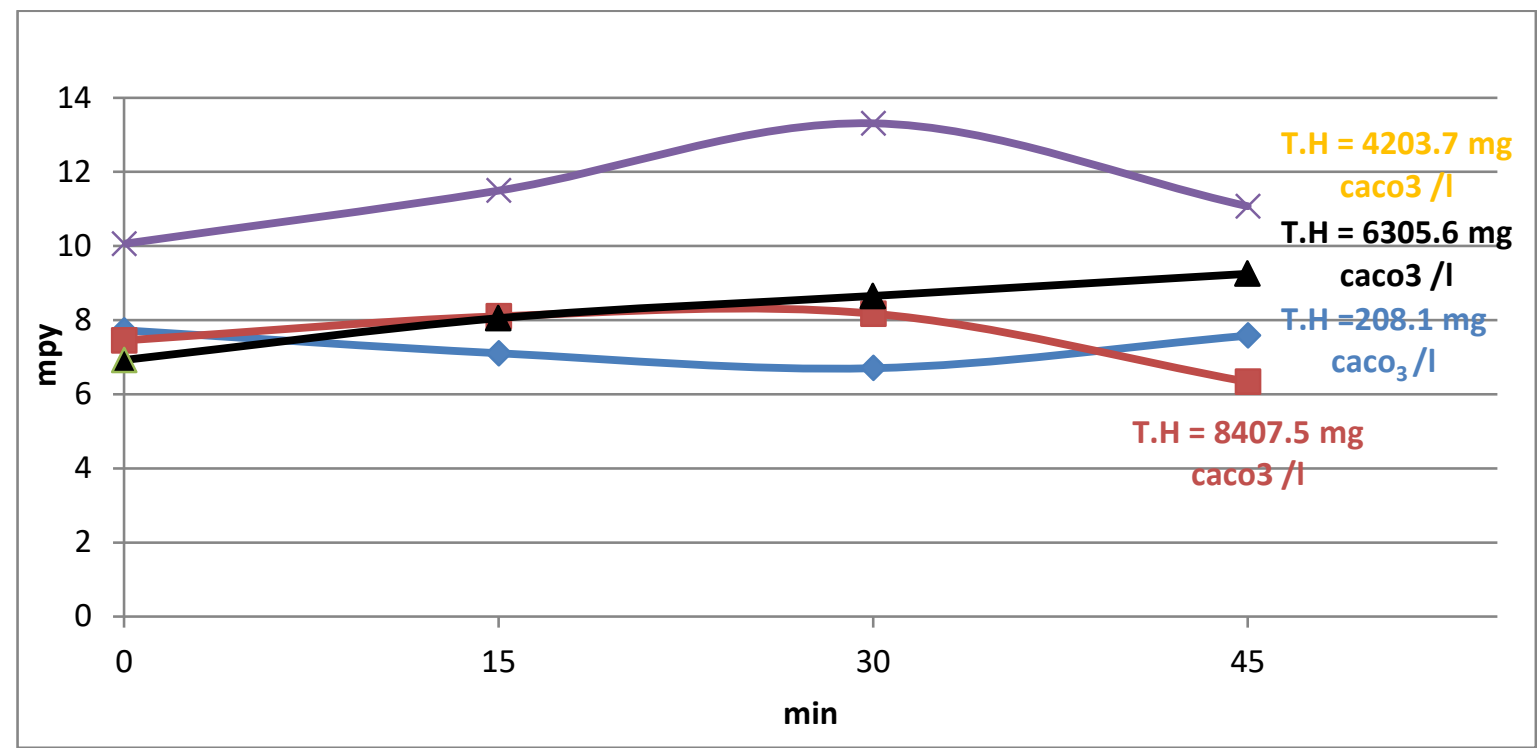

Figure 5: Variation of corrosion penetration rates (mpy) with immersion time periods (min) for the

\section{DISCUSSION.}

four water types

The findings were quite unexpected and suggest that an increase in the corrosion rate can be perceived accompanied by the total water hardness reduction for the three distilled water and seawater mixtures, which can be explained by the inability of softened hard water to form scales easily. In contrast, it is not the case for the samples that immersed and exposed to (GMMR); Ajdabiya water in which the lowest corrosion rate value was observed. It was noted that the weight loss started at room temperature $\left(25^{\circ} \mathrm{C}\right)$ and then decreased gradually when the samples immersed in a hot water as a result of coherent scale formation on the metal surface. It was also found that the immersion for more than 30 minutes in heated diluted seawater with $\mathrm{TH}$ of $(4203.7 \mathrm{mg}$ and $8407.5 \mathrm{mg})$ results in a sharp decrease in the corrosion rate caused by scales creation. Whereas (GMMR) water showed an increase in the corrosion rate due to dismissing the formed scales that thermally decomposed.

\section{CONCLUSION}

The effect of water hardness is positive as far as corrosion rates are concerned. This is due to the formation of alkaline and sulfate coherent scale on the metal surface. If heat transfer is involved, it will have a negative effect on the formed scale stability at more than 30 minutes of immersion time. The rate of corrosion increases with the percentage of dissolved oxygen added from distilled water. The more immersion time in hot water and more exposure time duration, the more corrosion resistance of the steel alloy as a result of the decrease in dissolved oxygen content. Bubbling air to keep constant oxygen concentration close to samples' surfaces, has produced difficulty in keeping other experimental parameters unaffected. Therefore, repeating the measurements without aeration could offer a better experimental parameters control.

\section{REFERENCES}

[1] Revie, R. W., \& Uhlig, H. H. (2008). Corrosion and Corrosion Control: An Introduction to Corrosion Science and Engineering (4th ed.). Hoboken, NJ: Willey.

[2] Ahmad, Z., (2006). Principles of Corrosion Engineering and Corrosion Control (6th ed.). Boston, MA: Elsevier/BH.

[3] Fontana, Mars G. (1987). Corrosion Engineering (3rd ed.). Toronto: McGraw-Hill.

[4] William D. Callister, Jr. David G. Rethwisch (1997). Materials Science and Engineering: An Introduction (9th ed.). New York: John Willey \& Sons.

[5] Revie, R. W., \& Uhlig, H. H. (2011). Uhlig's Corrosion Handbook (3rd ed.). Hoboken, NJ: Willey. 